\title{
Research Article \\ Effect of Lead on Human Middle Ear Epithelial Cells
}

\author{
Shin Hye Kim, Sun Hwa Shin, Yoon Young Go, Sung-Won Chae, and Jae-Jun Song $\mathbb{C}$ \\ Department of Otorhinolaryngology-Head and Neck Surgery, Korea University Medical Center, Korea University College of Medicine, \\ Seoul, Republic of Korea \\ Correspondence should be addressed to Jae-Jun Song; jjsong23@gmail.com
}

Received 28 August 2017; Revised 19 December 2017; Accepted 8 January 2018; Published 6 March 2018

Academic Editor: Jeong-Han Lee

Copyright (c) 2018 Shin Hye Kim et al. This is an open access article distributed under the Creative Commons Attribution License, which permits unrestricted use, distribution, and reproduction in any medium, provided the original work is properly cited.

Lead is a ubiquitous metal in the environment, but no studies have examined lead toxicity on the middle ear. Here, we investigated lead toxicity and its mechanism in human middle ear epithelial cells (HMEECs). Moreover, we investigated the protective effects of amniotic membrane extract (AME) and chorionic membrane extract (CME) against lead toxicity in HMEECs. Cell viability was analyzed using the cell counting kit, and reactive oxygen species (ROS) activity was measured using a cellular ROS detection kit. After lead(II) acetate trihydrate treatment, mRNA levels of various genes were assessed by semiquantitative real-time polymerase chain reaction. Following treatment with AME or CME after lead exposure, the changes in cell viability, ROS activity, and gene expression were analyzed. Exposure to $>100 \mu \mathrm{g} / \mathrm{mL}$ of lead(II) acetate trihydrate caused a significant decrease in cell viability and increased ROS production in HMEECs. Lead exposure significantly increased the mRNA expression of genes encoding inflammatory cytokines and mucins. Administration of AME or CME restored cell viability, reduced ROS activity, and ameliorated mRNA levels. Our findings suggest that environmental lead exposure is related to the development of otitis media, and AME and CME may have antioxidative and anti-inflammatory effects against lead toxicity.

\section{Introduction}

Otitis media $(\mathrm{OM})$ is a group of inflammatory diseases of the middle ear. The presence of inflammatory cytokines in middle ear fluid samples obtained from children with OM has been reported $[1,2]$. OM is a common inflammatory disease among children, and more than $50 \%$ of children experience one or more episodes of OM by the age of three years [3]. Fluid and mucus trapped in the middle ear by OM may lead to conductive hearing loss and delays in speech development and cognitive abilities [4]. Thus, the identification and control of potentially preventable risk factors for $\mathrm{OM}$, such as air pollution exposure, have significant implications for children's healthcare.

Lead is a common and versatile metal that is widely distributed in the environment, leading to human exposure. However, lead exposure through environmental (canned food, water pipes, soil, paint, plastics, household dust, air, etc.) or occupational routes can cause lead poisoning [5]. Particularly, in developing countries, lead is present in particulate form in the air and can be inhaled along with other heavy metals [6].
The major mechanism of lead toxicity is thought to be increased oxidative stress [7]. Lead induces an imbalance between the production of free radicals and detoxification of reactive intermediates or repair of the resulting damage. Oxidative stress occurs through two simultaneous pathways: generation of reactive oxygen species (ROS) and depletion of antioxidant reserves [8]. Ionic mechanisms and apoptosis have also been suggested as mechanisms of lead toxicity [9] . Lead can be substituted for other bivalent cations such as $\mathrm{Ca}^{2+}, \mathrm{Mg}^{2+}$, and $\mathrm{Fe}^{2+}$ as well as monovalent cations such as $\mathrm{Na}^{+}$, affecting various fundamental physiological processes [9]. Although lead toxicity does not occur through a single unifying mechanism, its ability to substitute for $\mathrm{Ca}^{2+}$ is a common factor in its toxicity [10]. Lead has been reported to induce activation of several cellular and molecular processes, such as apoptosis in cancer cell models and rats [11, 12].

Lead toxicity via ROS generation, ionic mechanism, and apoptosis has been demonstrated using in vitro and in vivo experimental models. However, no studies have examined the effects of this heavy metal on the middle ear. Therefore, this study evaluated the effects and mechanism of lead 
toxicity on human middle ear epithelial cells (HMEECs). In a previous study, we showed that amniotic membrane extract (AME) and chorionic membrane extract (CME) have antiinflammatory effects on HMEECs; therefore, we evaluated the protective effect of $\mathrm{AME}$ and $\mathrm{CME}$ on lead toxicity [13].

\section{Materials and Methods}

2.1. Cell Culture. HMEECs (kindly provided by Dr. David J. Lim, House Ear Institutes, Los Angeles, CA, USA) established using human papillomavirus E6/E7 genes for the study of normal cell biology and pathological processes associated with development of OM were used. HMEECs were maintained in a mixture of Dulbecco's modified Eagle's medium (Invitrogen, Carlsbad, CA, USA) and bronchial epithelial basal medium (Lonza, Basel, Switzerland) (1:1) [14] and kept in an incubator with a humidified atmosphere at $37^{\circ} \mathrm{C}$ containing $95 \%$ air and $5 \% \mathrm{CO}_{2}$. The growth medium was changed every third or fourth day. The doubling time of HMEECs is approximately 3 days, and cells were used for subsequent studies after 6 days. After approximately 1 week, the cells were stimulated with 10,50 , or $100 \mu \mathrm{g} / \mathrm{mL}$ lead(II) acetate trihydrate (Sigma, St. Louis, MO, USA) suspended in phosphate-buffered saline (PBS) for $24 \mathrm{~h}$. As a control group, HMEECs were treated with only PBS without lead(II) acetate trihydrate.

2.2. Cell Viability Assay. To analyze the viability of HMEECs, a cell viability assay was performed using a cell counting kit (CCK-8, Dojindo Laboratories, Kumamoto, Japan). HMEECs were seeded in 96-well plates, with each well containing $1 \times 10^{4}$ cells. The cells were treated with $0,6.25$, $12.5,25,50,100,200,300,400,500,600,700$, or $800 \mu \mathrm{g} / \mathrm{mL}$ of lead(II) acetate trihydrate on the following day. The cells were washed twice with PBS, and $10 \%$ CCK- 8 solution was added to each well after $24 \mathrm{~h}$. The plates were incubated for $2 \mathrm{~h}$ at $37^{\circ} \mathrm{C}$, and the contents of the plates were mixed at room temperature $\left(20-25^{\circ} \mathrm{C}\right)$ for $5 \mathrm{~min}$ using a shaker. The optical density was measured at $450 \mathrm{~nm}$ using a microplate reader (Spectra Max plus 384, Molecular Devices, Sunnyvale, CA, USA). The results were obtained from three repeated experiments using triplicate samples.

2.3. Cell Apoptosis Assay. After exposure to lead(II) acetate trihydrate for $24 \mathrm{~h}$, apoptotic cells were detected in real-time using a caspase-3 detection kit $\left(\mathrm{NucView}^{\mathrm{TM}} 488\right.$ Caspase3, Cat Number 4440, Biotium, Inc., Fremont, CA, USA). Following cell seeding, plates were warmed to $37^{\circ} \mathrm{C}$ for $30 \mathrm{~min}$ and then scanned using an IncuCyte Zoom system (Essen BioScience, Ann Arbor, MI, USA).

2.4. ROS Activity Assays. HMEECs $\left(1.5 \times 10^{4}\right)$ were treated with lead(II) acetate trihydrate for $24 \mathrm{~h}$. ROS activity in the cells was quantified using a $2^{\prime}, 7^{\prime}$-dichlorofluorescin diacetate (DCFDA) cellular ROS detection assay kit (Abcam, Cambridge, UK). Briefly, the cells were washed twice with PBS and then incubated with $100 \mu \mathrm{L}$ DCFDA in culture medium at $37^{\circ} \mathrm{C}$ for $30 \mathrm{~min}$. The cells were washed twice with PBS and analyzed using an IncuCyte Zoom system (Essen Bioscience). As a positive control to assess the ROS activity, $50 \mu \mathrm{g} / \mathrm{mL}$ tertbutyl hydrogen peroxide (TBHP) was used.

2.5. Real-Time Reverse Transcriptase Polymerase Chain Reaction. TNF- $\alpha$ and COX-2 are inflammatory cytokines genes related to the OM [15]. MUC5AC and MUC5B are mucins genes, and they reflect the mucins production and $\mathrm{OM}$ induction [16]. $E N a C-\alpha, E N a C-\beta$, and $E N a C-\gamma$ are genes encoding epithelial sodium channels and they reflect the mucociliary transport in the middle ear mucosa [17]. AQP4 is gene of aquaporin in middle ear mucosa and it reflects the homeostasis of the middle ear cavity [18]. To quantify the expression of TNF- $\alpha$, COX-2, MUC5AC, MUC5B, ENaC$\alpha, E N a C-\beta, E N a C-\gamma$, and $A Q P-4$ in HMEECs, real-time polymerase chain reaction (RT-PCR) was performed. After exposure to lead, RNA was extracted from HMEECs using TRIzol, and reverse transcription was performed using a cDNA synthesis kit (Takara Bio, Inc., Shiga, Japan).

RT-PCR was performed using an ABI Prism 7300 realtime PCR system (Applied Biosystems, Foster City, CA, USA). Each reaction mixture contained $10 \mu \mathrm{L}$ of LightCycler 480SYBR Green I Master (Roche, Mannheim, Germany), $1 \mu \mathrm{L}$ of $\mathrm{cDNA}$, and $5 \mathrm{pmol}$ each of sense and antisense primer in a final volume of $20 \mu \mathrm{L}$. Reaction mixtures were incubated at $95^{\circ} \mathrm{C}$ for $5 \mathrm{~min}$ to activate the FastStart Taq DNA Polymerase. This was followed by amplification for 45 cycles (one cycle: $15 \mathrm{~s}$ at $95^{\circ} \mathrm{C}, 30 \mathrm{~s}$ at $60^{\circ} \mathrm{C}$, and $30 \mathrm{~s}$ at $72^{\circ} \mathrm{C}$ ). The data were analyzed using LightCycler 480 software 1.5 (Roche). Results were obtained from three repeated experiments using triplicate samples.

2.6. Effect of Amniotic Membrane Extract and Chorionic Membrane Extract on Lead Exposure. Human amniotic and chorionic membranes are known to have anti-inflammatory effects [19]. Amniotic and chorionic membranes were obtained from the placenta of a pregnant woman who delivered at our tertiary center. The study was approved by the institutional review board of Korea University Guro Hospital (KUGH14239-002), and all participants provided written informed consent. The amniotic and chorionic membranes were washed with PBS. After homogenization and sonication of the membranes, AME and CME were obtained from the supernatant via three rounds of centrifugation at $13000 \mathrm{rpm}$ for $30 \mathrm{~min}$. To examine the protective effect of AME and CME on lead toxicity, the changes in cell viability, ROS activity, and gene expression after simultaneous treatment with AME and CME in lead-treated HMEECs were analyzed.

2.7. Statistical Analysis. All data are expressed as means \pm standard deviations. Statistical analyses were performed using SPSS ver. 12.0 (SPSS, Inc., Chicago, IL, USA). One-way analysis of variance (ANOVA) was used to determine significant differences between the control and experimental groups at each time or dose point. When significant differences were identified by ANOVA, Scheffe's $F$-test was used to correct for multiple comparisons. A $p$ value $<0.05$ was considered to indicate a statistically significant difference. 

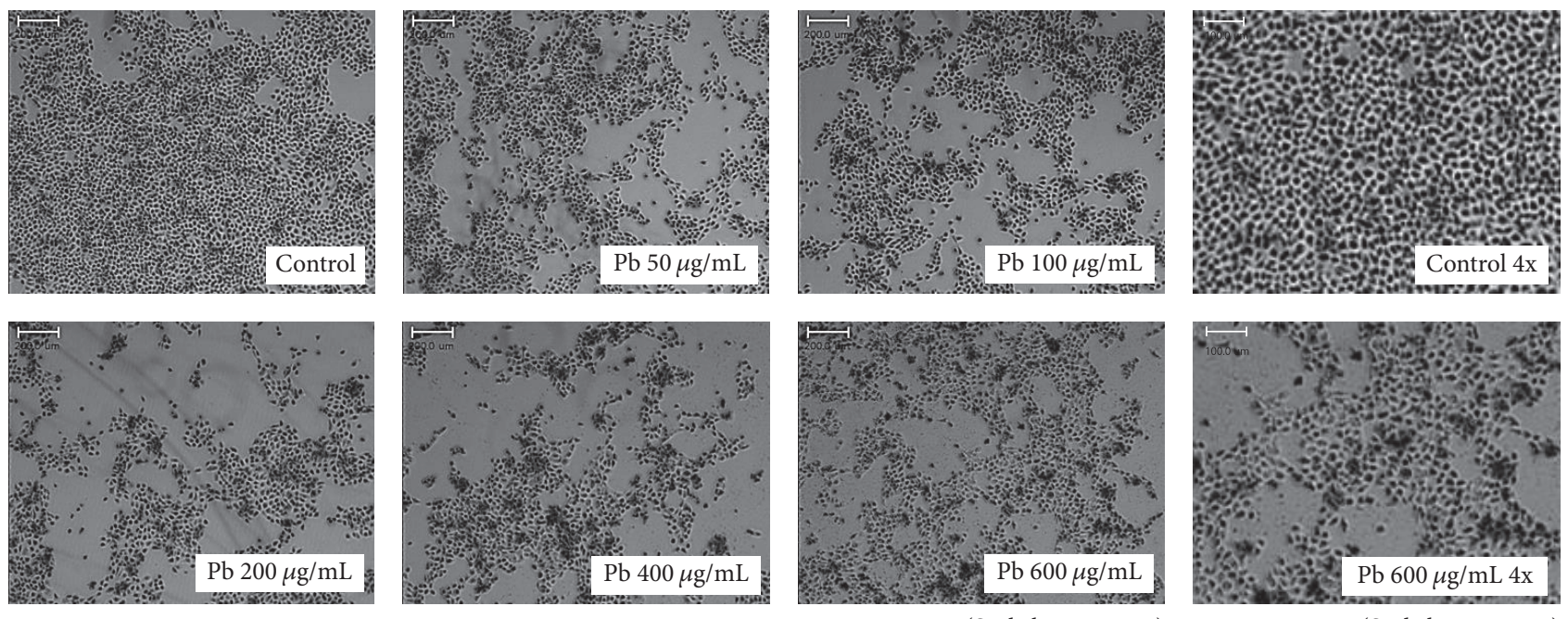

(Scale bar: $200 \mu \mathrm{m})$

(Scale bar: $100 \mu \mathrm{m}$ )

FIGURE 1: Cell morphology of human middle ear epithelial cells (HMEECs) following exposure to lead for $24 \mathrm{~h}$. As a control group, HMEECs were treated with only PBS without lead(II) acetate trihydrate: administration of lead(II) acetate trihydrate resulted in reduced cell size and cell detachment from the Petri dishes.

\section{Results}

3.1. Lead Altered the Morphology and Induced Apoptosis of HMEECs. The morphology of HMEECs was altered following exposure to lead(II) acetate trihydrate (Figure 1). The nuclei of control cells were round and homogeneously stained. Addition of lead(II) acetate trihydrate resulted in reduced cell size and cell detachment from the Petri dishes. Apoptotic cells were detected by fluorescence, and the numbers of apoptotic cells increased with increasing concentrations of the lead(II) acetate trihydrate (Figure 2).

3.2. Lead Reduced the Cell Viability of HMEECs. Cell viability assays (CCK-8) showed that exposure to more than $100 \mu \mathrm{M}$ of lead(II) acetate trihydrate for $24 \mathrm{~h}$ significantly decreased HMEECs viability compared to control cells (Figure 3).

\subsection{Lead Increased ROS Production in HMEECs. Increased} ROS activity was detected in cells exposed to $50-300 \mu \mathrm{g} / \mathrm{mL}$ of lead(II) acetate trihydrate compared to control cells (Figure 4). However, ROS activity was decreased in cells exposed to $>400 \mu \mathrm{g} / \mathrm{mL}$ lead(II) acetate trihydrate compared to control cells, perhaps because of cell death caused by the high concentration of lead.

3.4. Lead Altered Gene Expression in HMEECs. When cells were stimulated with $>50$ and $>100 \mu \mathrm{g} / \mathrm{mL}$ lead(II) acetate trihydrate for $24 \mathrm{~h}$, gene expression of TNF- $\alpha$ and COX-2 was significantly increased in HMEECs, respectively $(p<$ 0.05 , Figure 5(a)). Gene expression of $M U C 5 A C$ and $M U C 5 B$ in HMEECs significantly increased following stimulation with $>100$ and $>200 \mu \mathrm{g} / \mathrm{mL}$ of lead(II) acetate trihydrate for $24 \mathrm{~h}$, respectively $(p<0.05$, Figure 5(b)). Gene expression of $E N a C-\alpha, E N a C-\beta$, and $E N a C-\gamma$ significantly decreased when cells were stimulated with $>200,>50$, and $>50 \mu \mathrm{g} / \mathrm{mL}$ of lead(II) acetate trihydrate for $24 \mathrm{~h}$, respectively $(p<$ 0.05 , Figure $5(\mathrm{c}))$. Gene expression of $A Q P-4$ significantly increased when cells were stimulated with $400 \mu \mathrm{g} / \mathrm{mL}$ lead(II) acetate trihydrate for $24 \mathrm{~h}(p<0.05$, Figure 5(d)).

\subsection{Amniotic and Chorionic Membrane Extracts Reduced} Lead Toxicity. HMEECs were decreased in size, and nuclei were condensed following exposure to $600 \mu \mathrm{g} / \mathrm{mL}$ lead(II) acetate trihydrate; however, the morphology was recovered by treatment with AME or CME (Figure 6). Addition of AME or CME to $600 \mu \mathrm{g} / \mathrm{mL}$ lead(II) acetate trihydrate also decreased the number of apoptotic cells (Figure 7). The number of HMEECs was significantly reduced by $600 \mu \mathrm{g} / \mathrm{mL}$ lead(II) acetate trihydrate; however, the negative effect of lead on the cell viability of HMEECs was significantly reduced by administration of 100 and $200 \mu \mathrm{g} / \mathrm{mL}$ AME or CME (Figure 8 ). ROS activity was increased by administration of $600 \mu \mathrm{g} / \mathrm{mL}$ lead(II) acetate trihydrate; however, administration of 100 and $200 \mu \mathrm{g} / \mathrm{mL}$ AME or CME decreased ROS activity (Figure 9).

3.6. Amniotic and Chorionic Membrane Extracts Recovered Normal Gene Expression in HMEECs following Exposure to Lead. The increased expression of TNF- $\alpha$ and COX-2 following administration of $600 \mu \mathrm{g} / \mathrm{mL}$ lead(II) acetate trihydrate was decreased following administration of AME and CME (Figure 10(a)). The increased expression of MUC5AC and $M U C 5 B$ following exposure to $600 \mu \mathrm{g} / \mathrm{mL}$ lead(II) acetate trihydrate was also decreased following administration of AME and CME (Figure 10(b)). The decreased expression of $E N a C-\alpha, E N a C-\beta$, and $E N a C-\gamma$ following $600 \mu \mathrm{g} / \mathrm{mL}$ lead(II) acetate trihydrate administration was also recovered by AME 

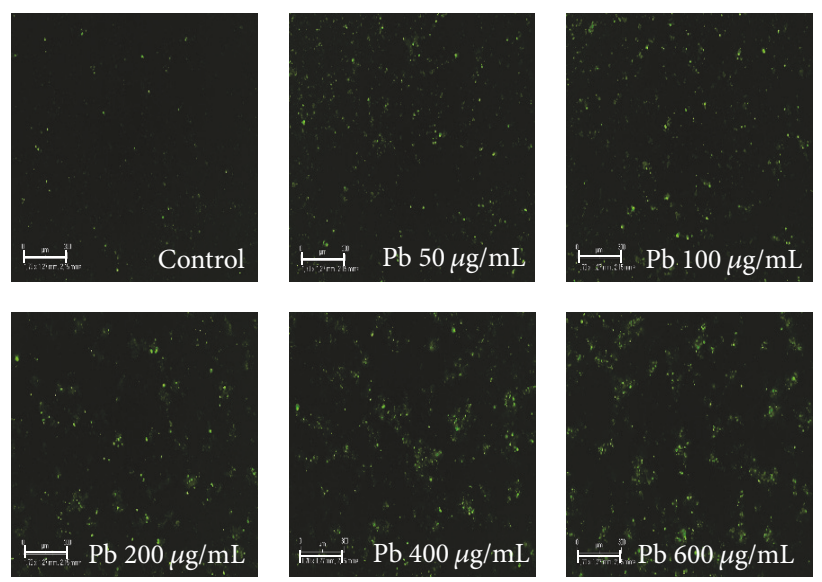

(Scale bar: $300 \mu \mathrm{m}$ )

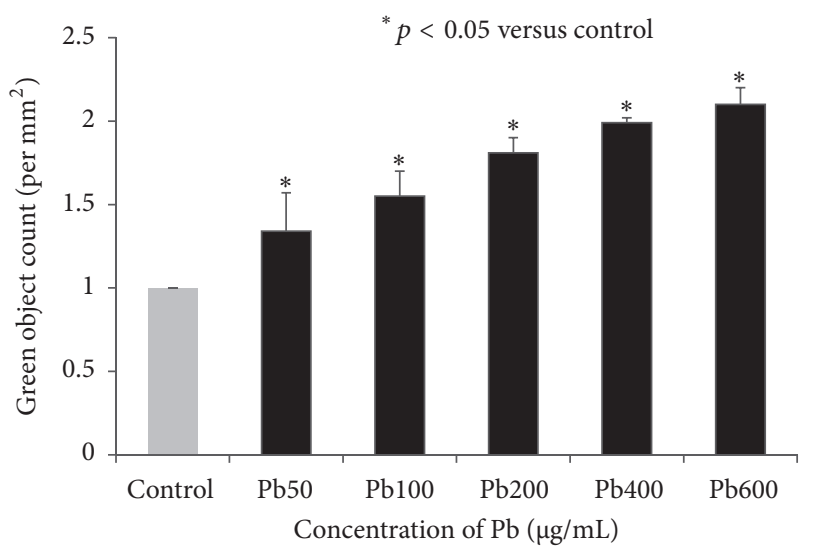

Figure 2: Apoptosis of human middle ear epithelial cells (HMEECs) following exposure to lead for $24 \mathrm{~h}$. Apoptotic cells were detected by fluorescence using an IncuCyte Zoom system: the numbers of apoptotic cells increased with increasing concentration of lead(II) acetate trihydrate. Error bars indicate the standard error of the mean (SEM).

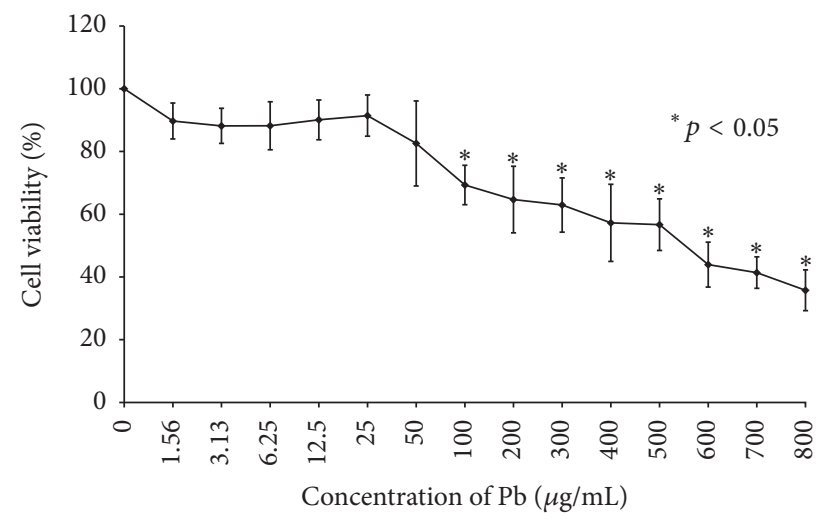

Figure 3: Cell viability of human middle ear epithelial cells (HMEECs) following exposure to lead: exposure to more than $100 \mu \mathrm{g} / \mathrm{mL}$ of lead(II) acetate trihydrate for $24 \mathrm{~h}$ significantly decreased HMEECs viability as compared to control cells. Error bars indicate the standard error of the mean (SEM).

and CME (Figure 10(c)). The increased expression of $A Q P$ 4 following $600 \mu \mathrm{g} / \mathrm{mL}$ lead(II) acetate trihydrate administration was decreased following administration of AME and CME (Figure 10(d)).

\section{Discussion}

Lead is an insidiously hazardous material that has the potential to cause irreversible negative health effects. Lead is known to interfere with numerous physiological functions, primarily affecting the central nervous, hematopoietic, hepatic, and renal systems [7, 20]. Lead is present in the form of airborne particulate matter, along with other heavy metals. We predicted that lead, similar to other air pollutants or smoke, can enter the middle ear space through the Eustachian tubes or via the systemic circulation. The potential for lead exposure to have adverse effects is heightened in children for three reasons: young children often place objects in their mouths, resulting in ingestion of dust and soil; intake of lead per unit of body weight is higher for children than for adults; and young children are undergoing rapid development and are consequently more vulnerable than adults to lead toxicity [21-23].

Lead persists in the environment as it is a nonbiodegradable material. Environmental exposure to lead became relatively high in the latter part of the 20th century, and concerted efforts were required to reduce lead exposure. In the late 1970s, the median blood lead level of US preschool children was $15 \mu \mathrm{g} / \mathrm{dL}$, and $88 \%$ of children had a level exceeding $10 \mu \mathrm{g} / \mathrm{dL}$ [24]. Based on the National Health and Nutrition Examination Survey (NHANES) (1991-1994, USA), the mean blood lead level among American children aged $1-5$ years was $2.7 \mu \mathrm{g} / \mathrm{dL}$, and $4.4 \%$ of these children $(890,000$ 

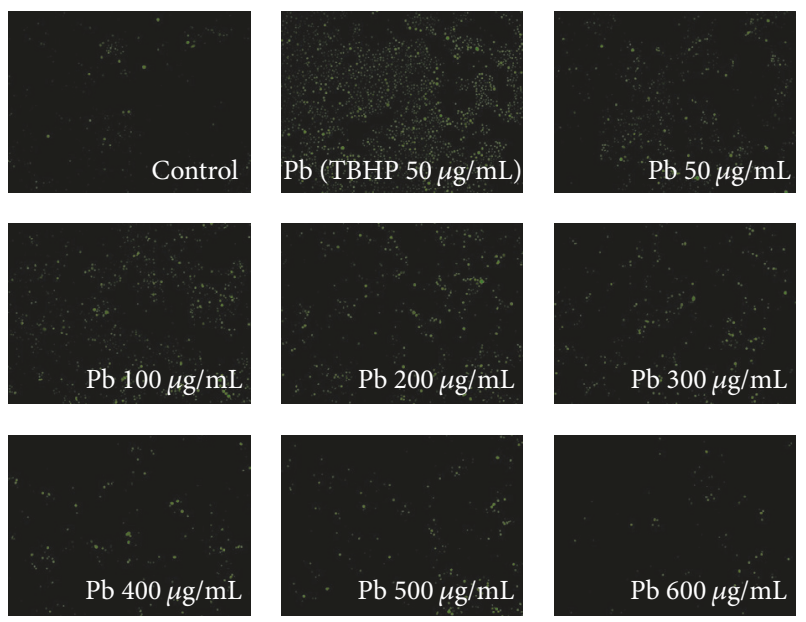

(DCFDA

$40 \mu \mathrm{g} / \mathrm{mL} / 10 \mathrm{x})$

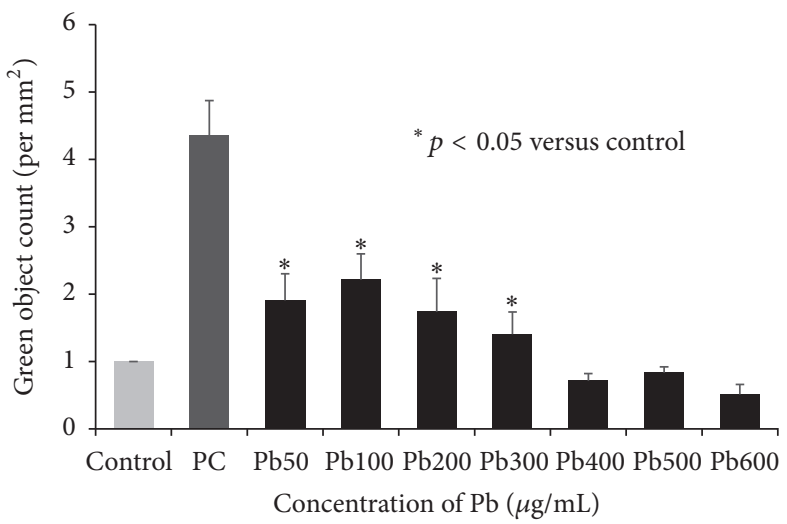

FIGURE 4: Reactive oxygen species (ROS) activity of human middle ear epithelial cells (HMEECs) following exposure to lead. As a positive control, $50 \mu \mathrm{g} / \mathrm{mL}$ tert-butyl hydrogen peroxide (TBHP) was used: ROS activity was increased in cells exposed to $50-300 \mu \mathrm{g} / \mathrm{mL}$ of lead(II) acetate trihydrate compared to control cells, but the ROS activity was decreased in cells exposed to $>400 \mu \mathrm{g} / \mathrm{mL}$ lead(II) acetate trihydrate compared to control cells. Error bars indicate the standard error of the mean (SEM).

in the USA population) had elevated blood lead levels [25]. In humans with chronic exposure of lead containing substances, immune, reproductive, and cardiovascular systems are adversely affected at blood levels of $10 \mu \mathrm{g} / \mathrm{dL}$ and even lower [26]. Children stratified into the low-lead group (lead $<10 \mu \mathrm{g} / \mathrm{dL}$ ) were reported to have a lower relative risk of respiratory illnesses and OM than those with lead $\geq 10 \mu \mathrm{g} / \mathrm{dL}$ [27].

Studies on lead toxicity have reported that the presence of lead in the body induces toxicological manifestations through various cellular, intracellular, and molecular mechanisms. Oxidative stress has been reported as a major mechanism of lead toxicity. Under the influence of lead, the onset of oxidative stress occurs via two distinct but simultaneously operating pathways: generation of ROS, such as hydroperoxides $\left(\mathrm{HO}^{\circ}\right)$ and singlet oxygen and hydrogen peroxide $\left(\mathrm{H}_{2} \mathrm{O}_{2}\right)$, and depletion of antioxidant reserves [14]. The ionic mechanism of lead toxicity mainly operates because lead can substitute for other bivalent cations such as $\mathrm{Ca}^{2+}$, $\mathrm{Mg}^{2+}$, and $\mathrm{Fe}^{2+}$ as well as monovalent cations such as $\mathrm{Na}^{+}$ (although bivalent cations are more readily substituted), affecting various fundamental physiological processes [19].

To investigate the mechanism of lead toxicity, considering the HMEECs with short-term $(24 \mathrm{~h})$ exposure of lead(II) acetate trihydrate, this in vitro study used higher concentration of lead (e.g., $100 \mu \mathrm{g} / \mathrm{mL}$ : 1000 times for $10 \mu \mathrm{g} / \mathrm{dL}$, in vivo criteria). We demonstrated that lead decreased the cell viability of HMEECs and increased ROS production. Lead also induced inflammatory mucins production. Inflammatory cytokines and mucins secretion play important roles in the development of OM. Inflammatory cytokines, including COX-2, TNF- $\alpha$, NF- $\kappa$ B, IL-1, IL-6, and IL-8, play a critical role in the initiation of mucosal changes, inflammatory response in the middle ear, and mucins secretion [15, 16]. Increased expression of genes encoding inflammatory cytokines and mucins has been detected in cigarette smoke-, diesel-, cadmium-, and Asian sand dust-induced OM [28$31]$. In the present study, lead caused increased gene expression of inflammatory cytokines (TNF- $\alpha$ and $C O X-2)$ and mucins (MUC5AC and MUC5B). Lead reduced the expression of genes encoding for epithelial sodium channels $(\mathrm{ENaC}$ $\alpha, E N a C-\beta$, and $E N a C-\gamma$ ) and consequently deteriorated mucociliary transport in the middle ear mucosa. Lead also induced gene expression of aquaporin $(A Q P-4)$ in the middle ear mucosa and consequently dysregulated the homeostasis of the middle ear cavity. Later, in vivo study confirming the concentration of lead inducing the toxicity will be needed.

The amniotic and chorionic membranes, located in the inner side of the placenta and formed by cubical cells and an inner mesodermal tissue, have been shown to have antiapoptotic, antiangiogenic, and anti-inflammatory effects on epithelial cells $[32,33]$. The mesenchymal stem cells obtained from mesoderm of human amniotic membrane possess immunosuppressive functions through soluble factors such as prostanoids and proteins [34]. AME, an extract of the human amniotic membrane, has also been shown to have anti-inflammatory effects. From the experiment using human corneal epithelial cells, homogenized human AME less than $3 \mathrm{kDa}$ had a greater capacity to decrease the inflammation and secretion of IL-6 and IL-8 [35]. Human AME has been proven to contain human neutrophil peptides, lysozyme, LL-37 (C-terminal part of the only human cathelicidin), bactericidal/permeability-increasing protein, calprotectin, and ubiquitin, and to show anti-inflammatory effects $[36,37]$. In the present study, both AME and CME showed 


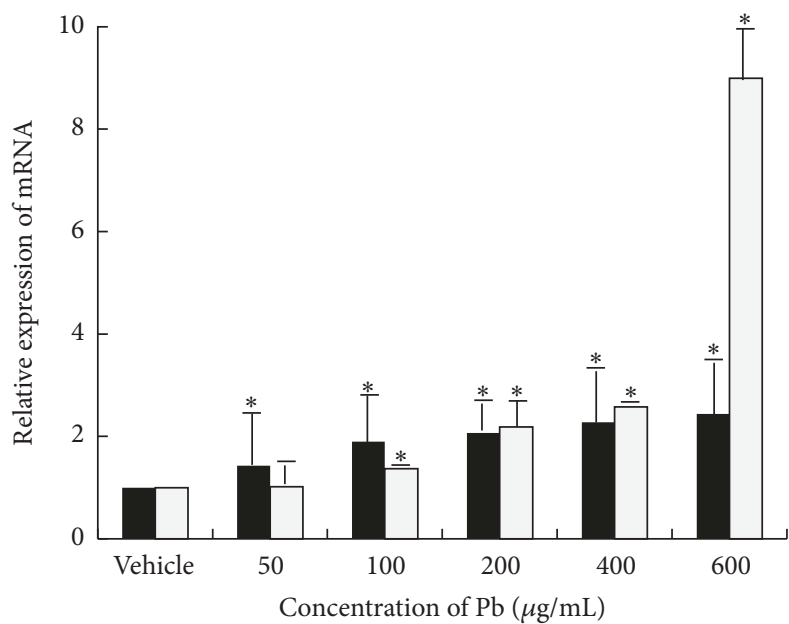

$\left({ }^{*} p<0.05\right)$
- $T N F-\alpha$

$\square \mathrm{COX}-2$

(a)

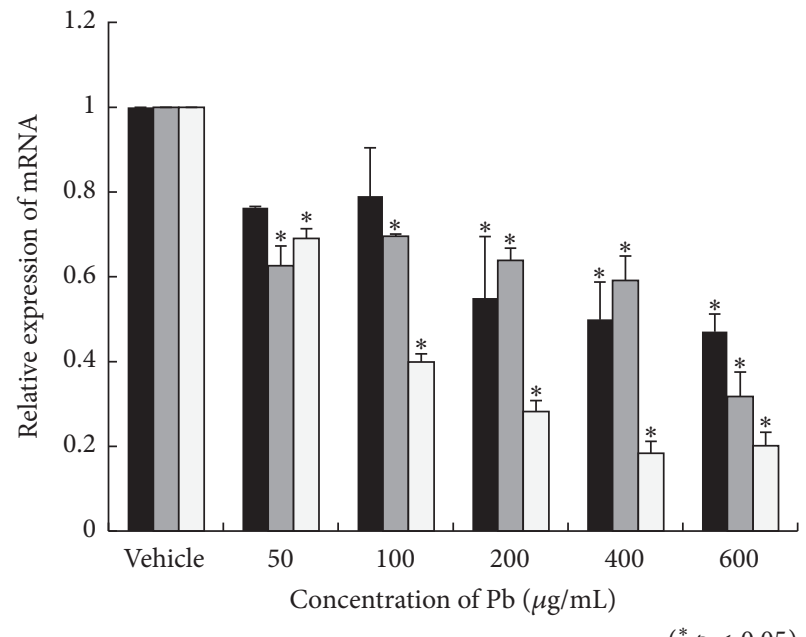

$\left({ }^{*} p<0.05\right)$

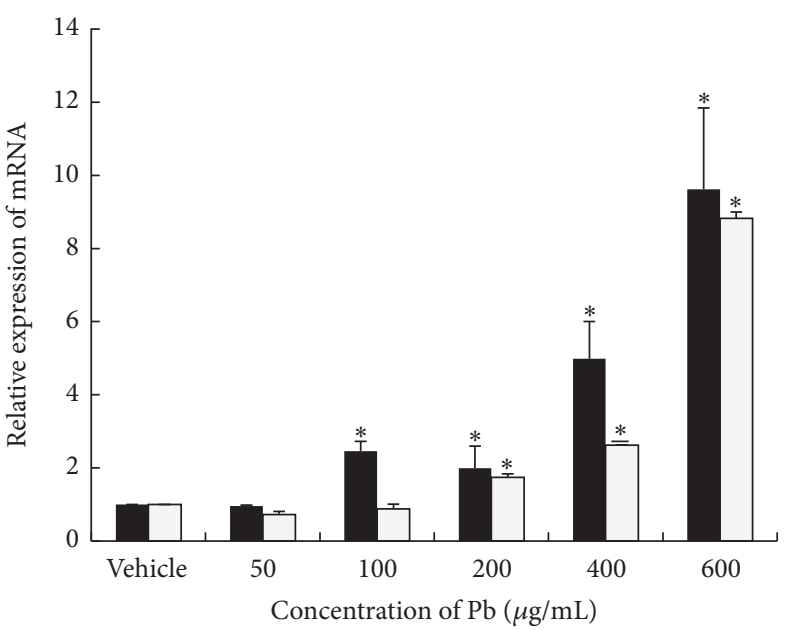

$\left({ }^{*} p<0.05\right)$
- MUC5AC

ㅁ MUC5B

(b)

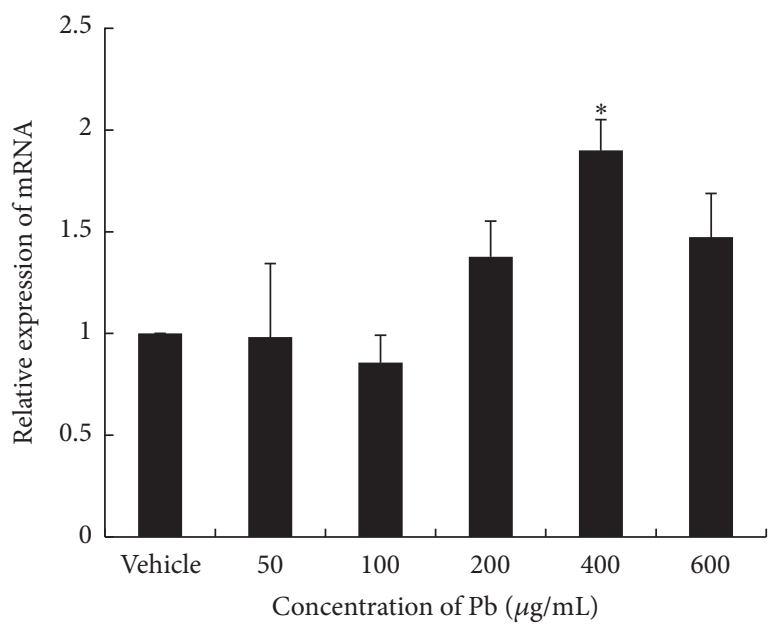

$\left({ }^{*} p<0.05\right)$

- ENaC- $\alpha$

- $E N a C-\beta$

口 $E N a C-\gamma$

(c)

(d)

FIGURE 5: Alteration of gene expression in human middle ear epithelial cells (HMEECs) following exposure to lead: lead(II) acetate trihydrate concentrations of $>50$ and $>100 \mu \mathrm{g} / \mathrm{mL}$ for $24 \mathrm{~h}$ significantly increased gene expression of TNF- $\alpha$ and COX-2 HMEECs, respectively (a). Lead(II) acetate trihydrate at $>100$ and $>200 \mu \mathrm{g} / \mathrm{mL}$ for $24 \mathrm{~h}$ significantly increased gene expression of MUC5AC and MUC5B in HMEECs, respectively (b). Lead(II) acetate trihydrate at $>200,>50$, and $>50 \mu \mathrm{g} / \mathrm{mL}$ for $24 \mathrm{~h}$ significantly decreased gene expression of $E N a C-\alpha, E N a C-\beta$, and $E N a C-\gamma$, respectively (c). Lead(II) acetate trihydrate at $400 \mu \mathrm{g} / \mathrm{mL}$ for $24 \mathrm{~h}$ significantly increased gene expression of $A Q P-4$ (d). Error bars indicate the standard error of the mean (SEM).

antiapoptotic and anti-inflammatory effects on HMEECs following exposure to lead. The first clinical use of AME was to treat epithelial defects of the cornea [38], and it is used for the treatment of ocular and dermatologic injuries and diseases. Despite the fact that therapies with AME have been used to ameliorate acute and chronic inflammatory diseases of eye and skin, the precise mechanisms by which these cells or soluble factors exert their function are yet poorly understood. Additional experiments to confirm what components of AME and CME show antiapoptotic and antiinflammatory effects will be needed.

\section{Conclusions}

Our study revealed a causal relationship between environmental lead exposure and OM. One limitation of this in vitro 

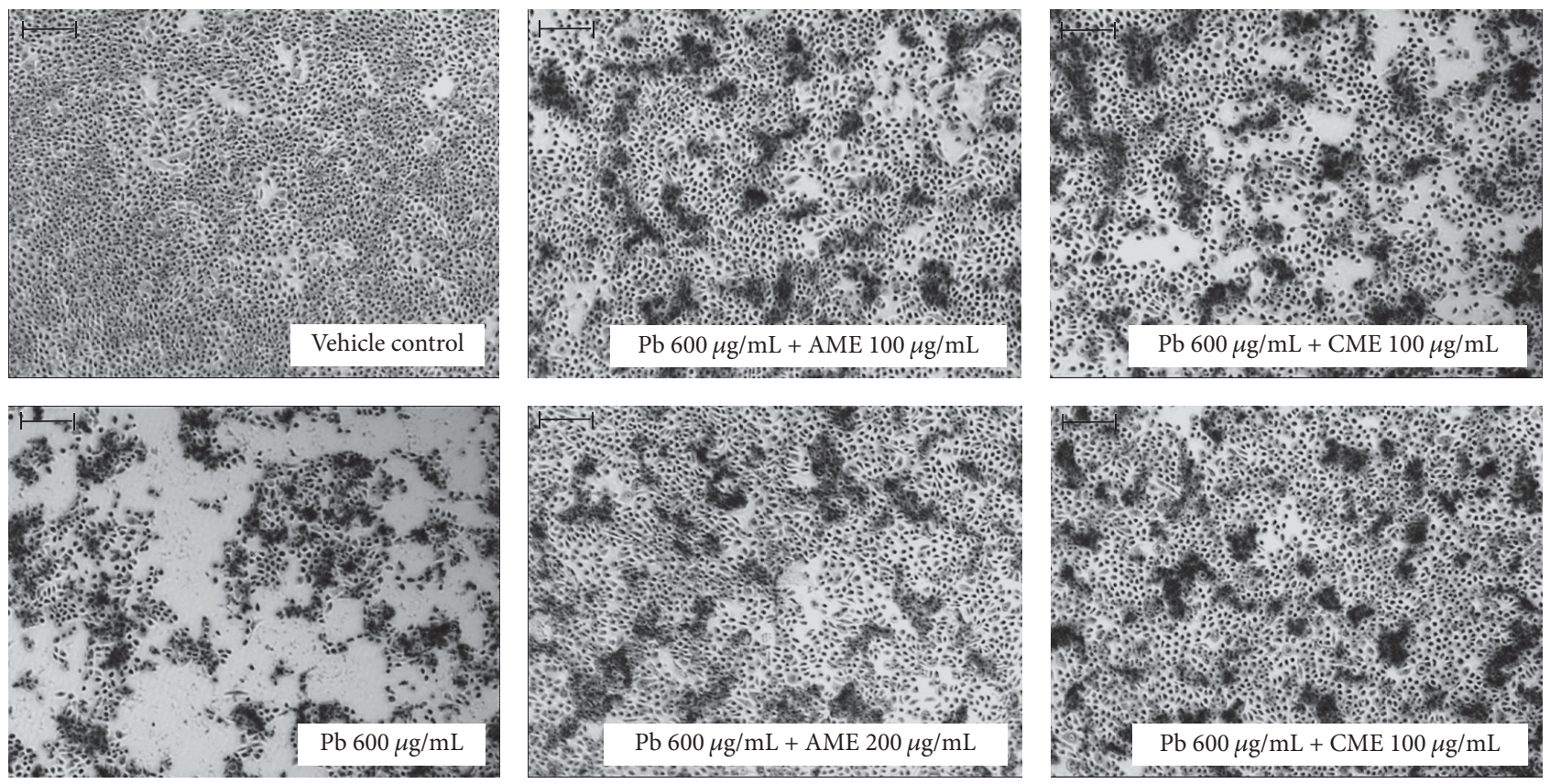

(Scale bar: $200 \mu \mathrm{m}$ )

FIGURE 6: Effect of amniotic membrane extract (AME) and chorionic membrane extract (CME) on cell morphology in human middle ear epithelial cells (HMEECs) following exposure to lead for $24 \mathrm{~h}$ : reduced cell size and condensed nuclei by exposure to $600 \mu \mathrm{g} / \mathrm{mL}$ lead(II) acetate trihydrate was recovered by treatment with AME or CME.
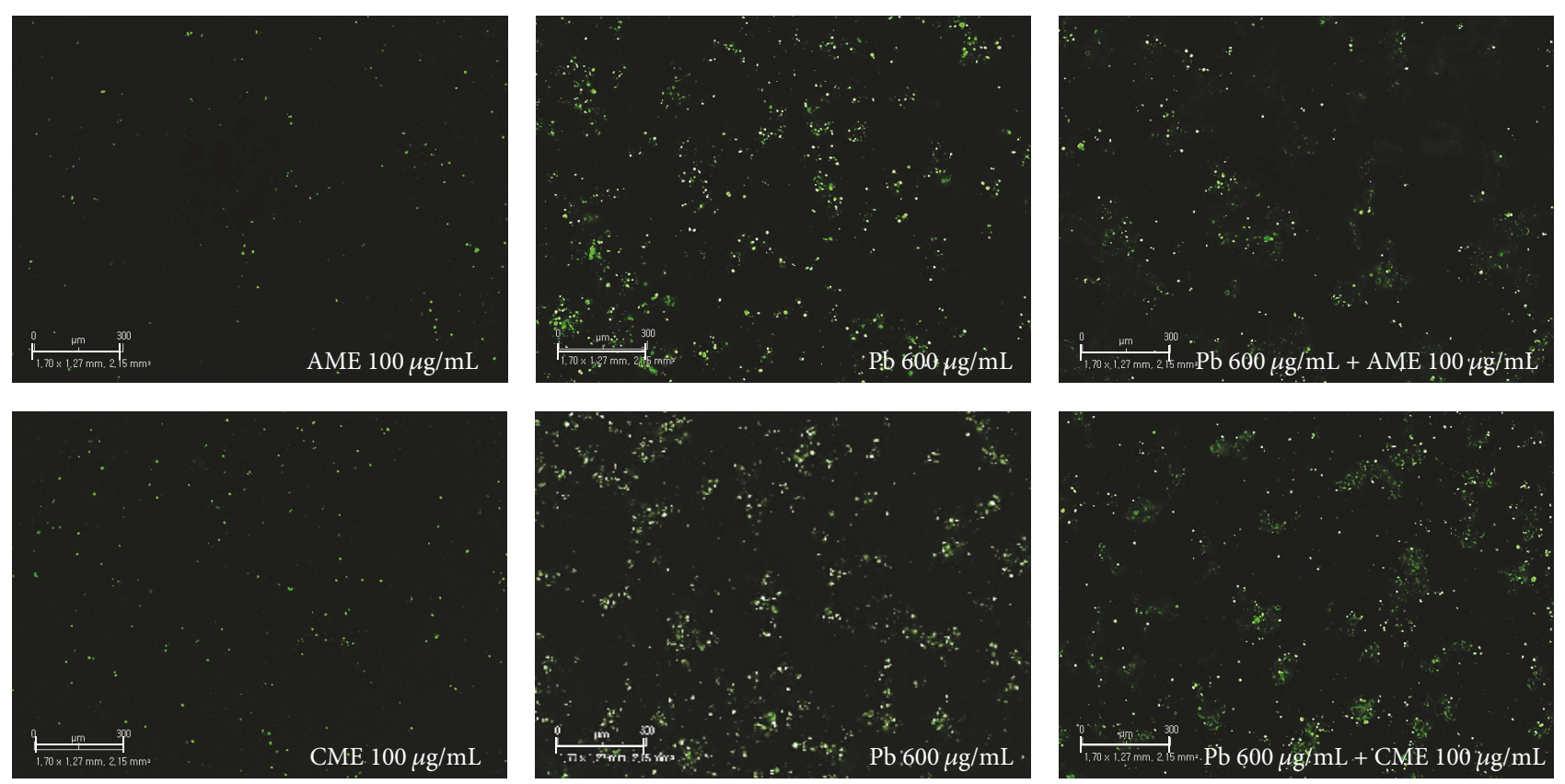

(Scale bar: $300 \mu \mathrm{m})$

FIGURE 7: Effect of amniotic membrane extract (AME) and chorionic membrane extract (CME) on apoptosis in human middle ear epithelial cells (HMEECs) following exposure to lead for $24 \mathrm{~h}$ : addition of $100 \mu \mathrm{g} / \mathrm{mL}$ AME or CME to cells treated with $600 \mu \mathrm{g} / \mathrm{mL}$ lead(II) acetate trihydrate decreased the number of apoptotic cells. 


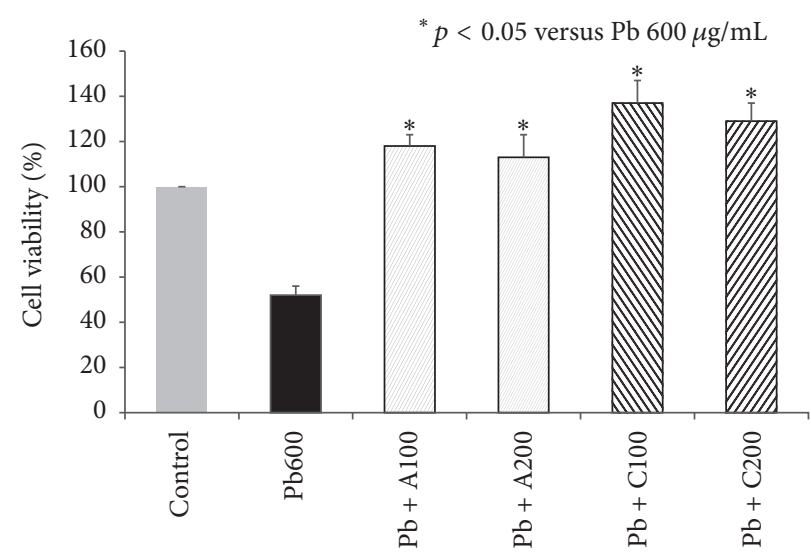

FIGURE 8: Effect of amniotic membrane extract (AME) and chorionic membrane extract (CME) on cell viability of human middle ear epithelial cells (HMEECs) following exposure to lead for $24 \mathrm{~h}$ : administration of 100 and $200 \mu \mathrm{g} / \mathrm{mL}$ AME or CME significantly increased cell viability of HMEECs exposed to $600 \mu \mathrm{g} / \mathrm{mL}$ lead(II) acetate trihydrate. Error bars indicate the standard error of the mean (SEM).
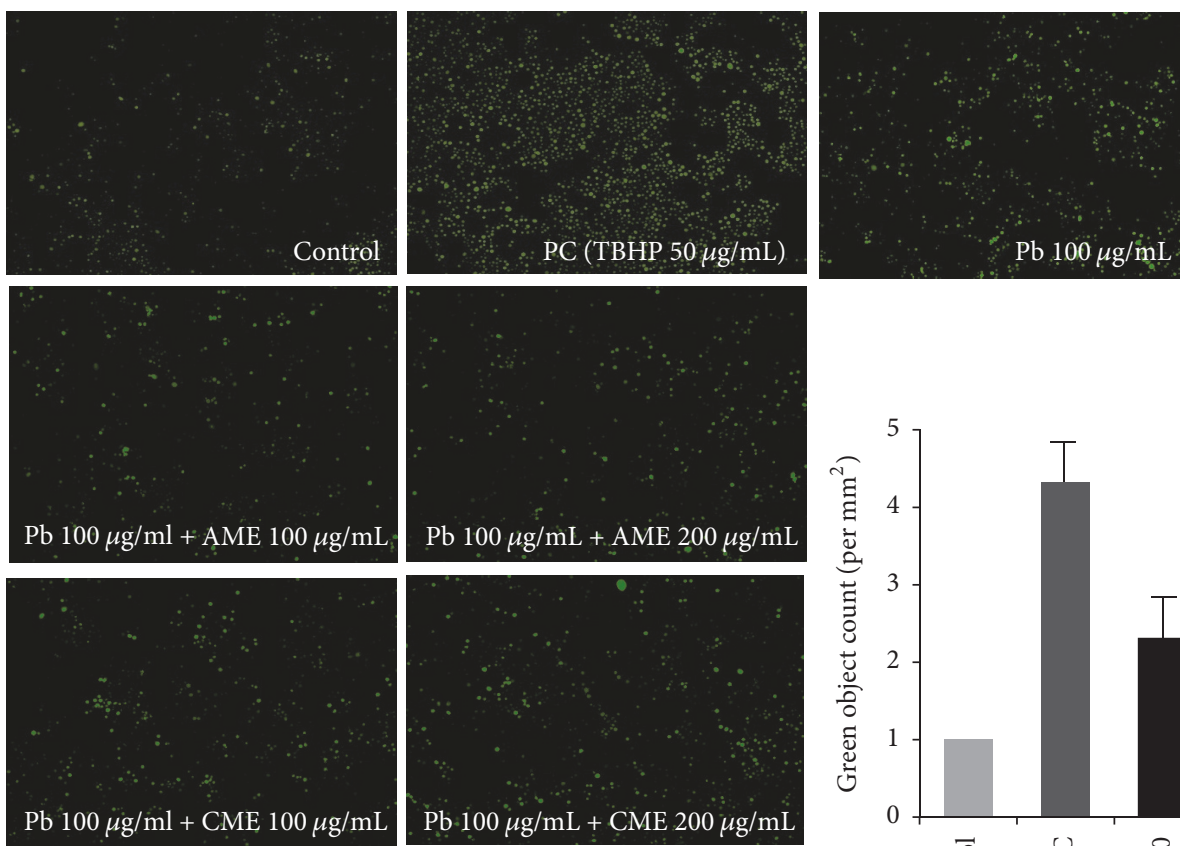

(DCFDA $40 \mu \mathrm{M} / 10 \mathrm{x})$

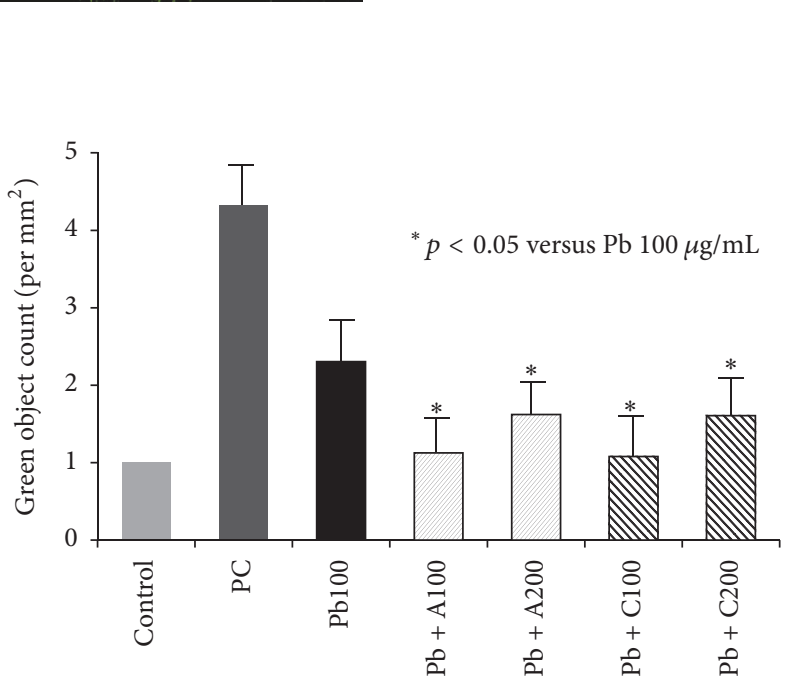

FIGURE 9: Effect of amniotic membrane extract (AME) and chorionic membrane extract (CME) on reactive oxygen species (ROS) activity of human middle ear epithelial cells (HMEECs) following exposure to lead. As a positive control, $50 \mu \mathrm{g} / \mathrm{mL}$ tert-butyl hydrogen peroxide (TBHP) was used: administration of 100 and $200 \mu \mathrm{g} / \mathrm{mL}$ AME or CME significantly decreased ROS activity in HMEECs exposed to $100 \mu \mathrm{g} / \mathrm{mL}$ lead(II) acetate trihydrate. Error bars indicate the standard error of the mean (SEM).

study is that we evaluated lead toxicity in the cell model of the human middle ear. In the future, in vivo studies and clinical trials are needed to confirm the toxicity of lead and protective effects of AME and CME in the middle ear.

\section{Disclosure}

An earlier version of this experiment was presented as a poster at 2017 Korean Society of Otorhinolaryngology-Head and Neck Surgery (KORL-HNS) meeting. The funders had no role in study design, data collection and analysis, decision to publish, or preparation of the manuscript.

\section{Conflicts of Interest}

The authors declare that the research was conducted in the absence of any commercial or financial relationships that could be construed as potential conflicts of interest. 


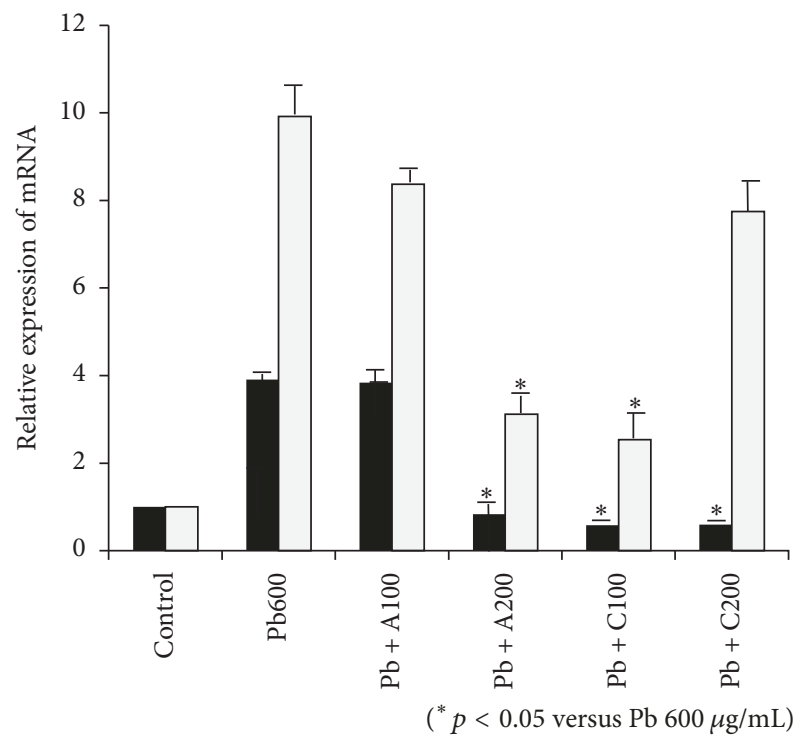

- $T N F-\alpha$

$\square C O X-2$

(a)

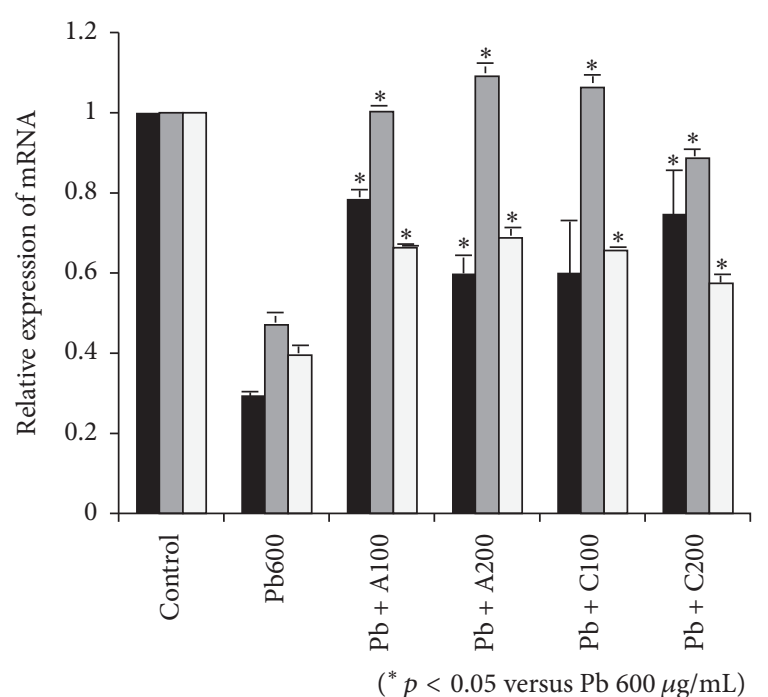

$E N a C-\alpha$

ENaC- $\beta$

$\square E N a C-\gamma$

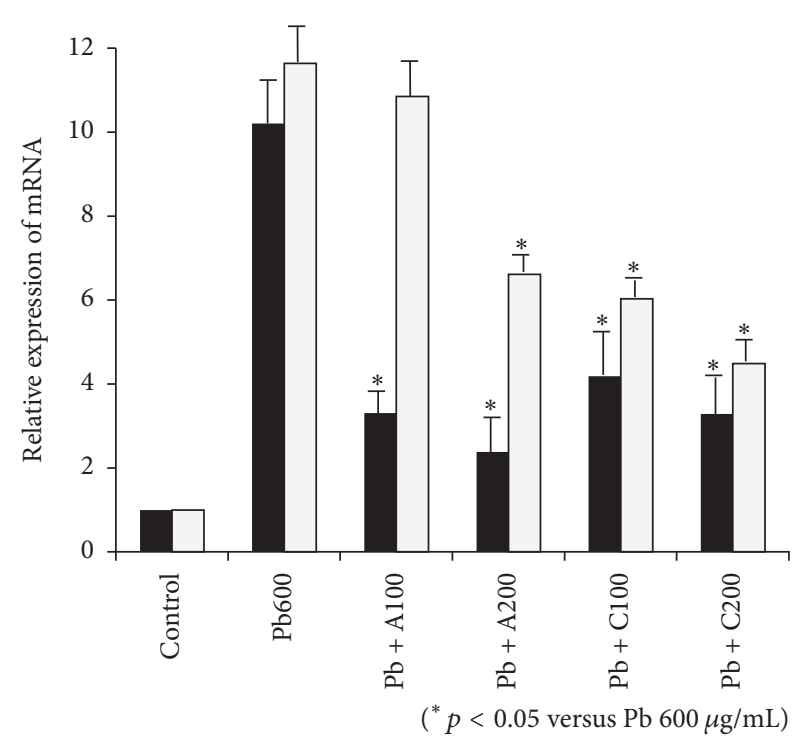

- MUC5AC

$\square \quad M U C 5 B$

(b)

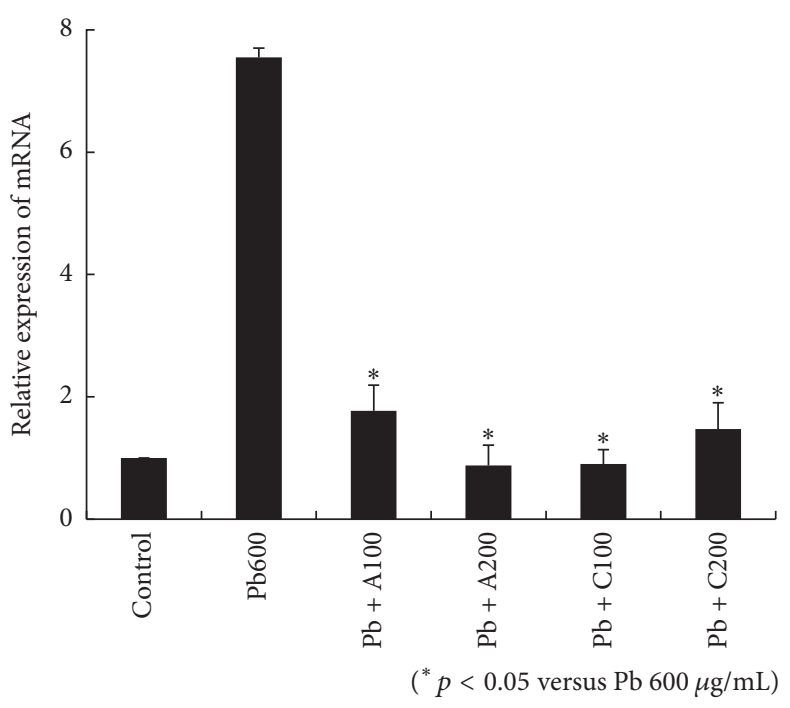

(d)

FIGURE 10: Effect of amniotic membrane extract (AME) and chorionic membrane extract (CME) on alterations of gene expression in human middle ear epithelial cells (HMEECs) following exposure to lead: administration of AME and CME decreased gene expression of TNF- $\alpha$ and COX-2 (a), MUC5AC, MUC5B (b), and AQP-4 (d) in HMEECs exposed to $600 \mu \mathrm{g} / \mathrm{mL}$ lead(II) acetate trihydrate. Administration of AME and CME increased gene expression of ENaC- $\alpha, E N a C-\beta$, and $E N a C-\gamma$ (c) in HMEECs exposed to $600 \mu \mathrm{g} / \mathrm{mL}$ lead(II) acetate trihydrate. Error bars indicate the standard error of the mean (SEM).

\section{Authors' Contributions}

Shin Hye Kim analyzed the results and wrote the manuscript. Sun Hwa Shin and Yoon Young Go performed the experiment. Jae-Jun Song designed this study and revised the manuscript with Sung-Won Chae. All authors read and approved the final manuscript.

\section{Acknowledgments}

This work was supported by a grant from the Korea Health Technology R\&D Project through the Korea Health Industry Development Institute (KHIDI), funded by the Ministry of Health \& Welfare, Republic of Korea (Grant no. HI15C2809). 


\section{References}

[1] S. K. Juhn, W. J. Garvis, C. T. Le, C. J. Lees, and C. S. Kim, "Determining otitis media severity from middle ear fluid analysis," Annals of Otology, Rhinology \& Laryngology, vol. 103, no. 5, pp. 43-45, 1994.

[2] R. F. Yellon, W. J. Doyle, T. L. Whiteside, W. F. Diven, A. R. March, and P. Fireman, "Cytokines, Immunoglobulins, and Bacterial Pathogens in Middle Ear Effusions," Archives of Otolaryngology-Head and Neck Surgery, vol. 121, no. 8, pp. 865869, 1995.

[3] H. J. Hoffman, K. A. Daly, K. E. Bainbridge et al., "Panel I: Epidemiology, natural history, and risk factors," Otolaryngology - Head and Neck Surgery (United States), vol. 148, no. 4, pp. E1E25, 2013.

[4] J. O. Klein, “The burden of otitis media," Vaccine, vol. 19, no. 1, pp. S2-S8, 2000.

[5] M. A. Smith, "Lead in history," in The Environmental Toxicology and Child Health, R. Lansdown and W. Yule, Eds., pp. 7-24, Croom Helm, London, UK, 1984.

[6] X. LI, Y. ZHANG, M. TAN et al., "Atmospheric lead pollution in fine particulate matter in Shanghai, China," Journal of Environmental Sciences, vol. 21, no. 8, pp. 1118-1124, 2009.

[7] G. Flora, D. Gupta, and A. Tiwari, "Toxicity of lead: a review with recent updates," Interdisciplinary Toxicology, vol. 5, no. 2, pp. 47-58, 2012.

[8] S. J. S. Flora, "Nutritional components modify metal absorption, toxic response and chelation therapy," Journal of Nutritional and Environmental Medicine, vol. 12, no. 1, pp. 53-67, 2002.

[9] T. I. Lidsky and J. S. Schneider, "Lead neurotoxicity in children: basic mechanisms and clinical correlates," Brain, vol. 126, part 1, pp. 5-19, 2003.

[10] J. P. Bressler and G. W. Goldstein, "Mechanisms of lead neurotoxicity," Biochemical Pharmacology, vol. 41, no. 4, pp. 479-484, 1991.

[11] C. G. Yedjou, J. N. Milner, C. B. Howard, and P. B. Tchounwou, "Basic apoptotic mechanisms of lead toxicity in human leukemia (Hl-60) cells," International Journal of Environmental Research and Public Health, vol. 7, no. 5, pp. 2008-2017, 2010.

[12] L.-H. Xu, F.-F. Mu, J.-H. Zhao et al., "Lead induces apoptosis and histone hyperacetylation in rat cardiovascular tissues," PLOS ONE, vol. 10, no. 6, Article ID e0129091, 2015.

[13] M. K. Yadav, Y. Y. Go, S. H. Kim, S. Chae, and J. Song, "Antimicrobial and Antibiofilm Effects of Human Amniotic/Chorionic Membrane Extract on Streptococcus pneumoniae," Frontiers in Microbiology, vol. 8, 2017.

[14] Y.-M. Chun, S.-K. Moon, D. E. Brackmann et al., "Immortalization of normal adult human middle ear epithelial cells using a retrovirus containing the E6/E7 genes of human papillomavirus type 16," Annals of Otology, Rhinology \& Laryngology, vol. 111, no. 6, pp. 507-517, 2002.

[15] H. Y. Lee, Y. I. Kim, J. W. Lee, J. Y. Byun, M. S. Park, and S. G. Yeo, "Decreased expression of TLR-9 and cytokines in the presence of bacteria in patients with otitis media with effusion," Clinical and Experimental Otorhinolaryngology, vol. 6, no. 4, pp. 195200, 2013.

[16] J. E. Kerschner, "Mucin gene expression in human middle ear epithelium," The Laryngoscope, vol. 117, no. 9, pp. 1666-1676, 2007.
[17] E. J. Son, S. H. Kim, H. Y. Park et al., "Activation of epithelial sodium channel in human middle ear epithelial cells by dexamethasone," European Journal of Pharmacology, vol. 602, no. 2-3, pp. 383-387, 2009.

[18] L. M. Morris, J. M. DeGagne, J. B. Kempton, F. Hausman, and D. R. Trune, "Mouse middle ear ion homeostasis channels and intercellular junctions," PLoS ONE, vol. 7, no. 6, Article ID e39004, 2012.

[19] U. Manuelpillai, Y. Moodley, C. V. Borlongan, and O. Parolini, "Amniotic membrane and amniotic cells: Potential therapeutic tools to combat tissue inflammation and fibrosis?" Placenta, vol. 32, no. 4, pp. S320-S325, 2011.

[20] K. Kalia and S. J. S. Flora, "Strategies for safe and effective therapeutic measures for chronic arsenic and lead poisoning," Journal of Occupational Health, vol. 47, no. 1, pp. 1-21, 2005.

[21] World Health Organization, "Environmental health criteria 165: Inorganic lead," in Proceedings of the International Program on Chemical Safety, Geneva, Switzerland, 1995.

[22] P. Mushak, "Perspective. Defining lead as the premiere environmental health issue for children in America: Criteria and their quantitative application," Environmental Research, vol. 59, no. 2, pp. 281-309, 1992.

[23] S. Tong and A. J. McMichael, "The magnitude, persistence and public health significance of cognitive effects of environmental lead exposure in childhood," Journal of Environmental Medicine, vol. 1, no. 2, pp. 103-110, 1999.

[24] K. R. Mahaffey, J. L. Annest, J. Roberts, and R. S. Murphy, "National estimates of blood lead levels: United States, 19761980. Association with selected demographic and socioeconomic factors," The New England Journal of Medicine, vol. 307, no. 10 , pp. 573-579, 1982.

[25] J. L. Pirkle, R. B. Kaufmann, D. J. Brody, T. Hickman, E. W. Gunter, and D. C. Paschal, "Exposure of the US population to lead, 1991-1994," Environmental Health Perspectives, vol. 106, no. 11, pp. 745-750, 1998.

[26] World Health Organization, "Childhood lead poisoning," Geneva, Switzerland, 2010.

[27] P. Mushak, Lead and Public Health: Science, Risk and Regulation, Elsevier, 1st edition, 2011.

[28] D. Preciado, E. Kuo, S. Ashktorab, P. Manes, and M. Rose, "Cigarette smoke activates NF $\kappa \mathrm{B}$-mediated Tnf- $\alpha$ release from mouse middle ear cells," The Laryngoscope, vol. 120, no. 12, pp. 2508-2515, 2010.

[29] J.-J. Song, J. D. Lee, B. D. Lee, S. W. Chae, and M. K. Park, "Effect of diesel exhaust particles on human middle ear epithelial cells," International Journal of Pediatric Otorhinolaryngology, vol. 76, no. 3, pp. 334-338, 2012.

[30] J. J. Song, J. Y. Kim, A. S. Jang et al., "Effect of cadmium on human middle ear epithelial cells," The Journal of International Advanced Otology, vol. 11, no. 3, pp. 183-187, 2015.

[31] J. Chang, Y. Go, M. K. Park, S.-W. Chae, S.-H. Lee, and J.-J. Song, "Asian sand dust enhances the inflammatory response and mucin gene expression in the middle ear," Clinical and Experimental Otorhinolaryngology, vol. 9, no. 3, pp. 198-205, 2016.

[32] A. Gupta, S. D. Kedige, and K. Jain, "Amnion and chorion membranes: potential stem cell reservoir with wide applications in periodontics," International Journal of Biomaterials, vol. 2015, Article ID 274082, 9 pages, 2015.

[33] C. M. Zelen, R. J. Snyder, T. E. Serena, and W. W. Li, “The use of human amnion/chorion membrane in the clinical setting for 
lower extremity repair: a review," Clinics in Podiatric Medicine and Surgery, vol. 32, no. 1, pp. 135-146, 2015.

[34] F. S. Magaña-Guerrero, A. Domínguez-López, P. MartínezAboytes, B. Buentello-Volante, and Y. Garfias, "Human Amniotic Membrane Mesenchymal Stem Cells inhibit Neutrophil Extracellular Traps through TSG-6," Scientific Reports, vol. 7, no. 1, Article ID 12426, 2017.

[35] H.-N. Lee, R. Bernardo, G.-Y. Han et al., "Human amniotic membrane extracts have anti-inflammatory effects on damaged human corneal epithelial cells in vitro," Journal of Hard Tissue Biology, vol. 25, no. 3, pp. 282-287, 2016.

[36] H. Yoshio, M. Tollin, G. H. Gudmundsson et al., "Antimicrobial polypeptides of human vernix caseosa and amniotic fluid: Implications for newborn innate defense," Pediatric Research, vol. 53, no. 2, pp. 211-216, 2003.

[37] H. He, W. Li, S. Chen et al., "Suppression of activation and induction of apoptosis in RAW264.7 cells by amniotic membrane extract," Investigative Ophthalmology and Visual Science, vol. 49, pp. 4468-4475, 2008.

[38] P. Bonci, P. Bonci, and A. Lia, "Suspension made with amniotic membrane: Clinical trial," European Journal of Ophthalmology, vol. 15, no. 4, pp. 441-445, 2005. 


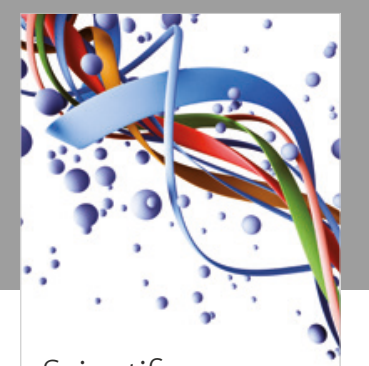

Scientifica
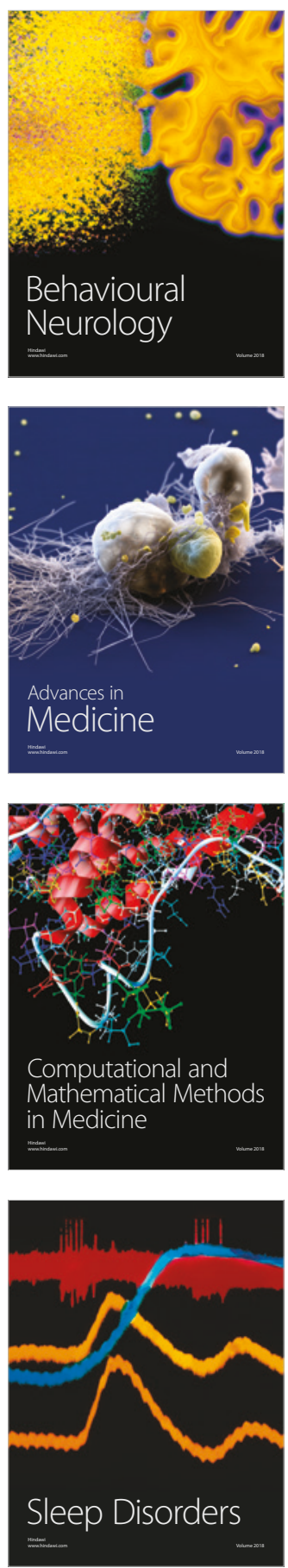

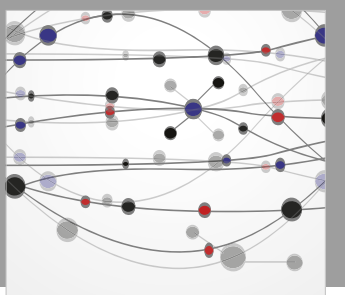

The Scientific World Journal

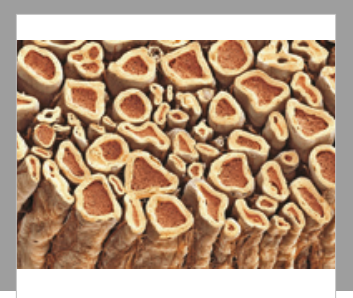

Case Reports in

Neurological Medicine

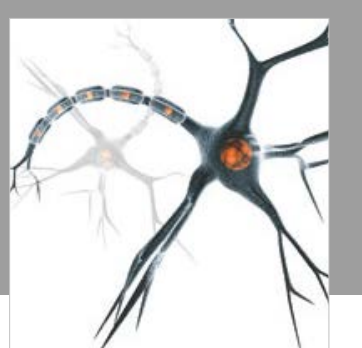

Neural Plasticity

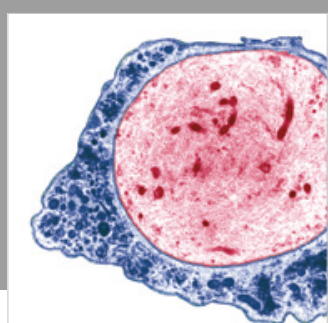

Multiple Sclerosis

International

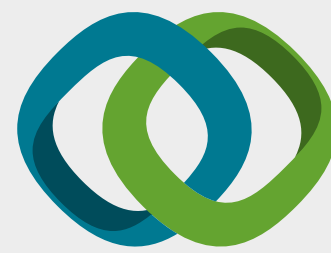

Hindawi

Submit your manuscripts at

www.hindawi.com
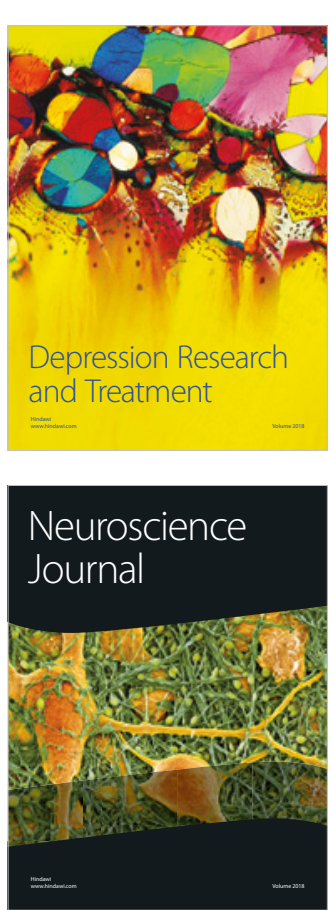

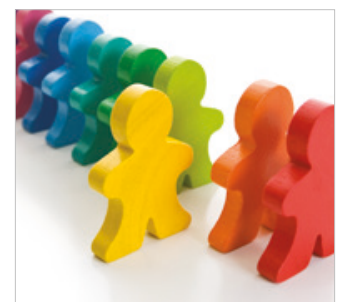

Autism

Research and Treatment
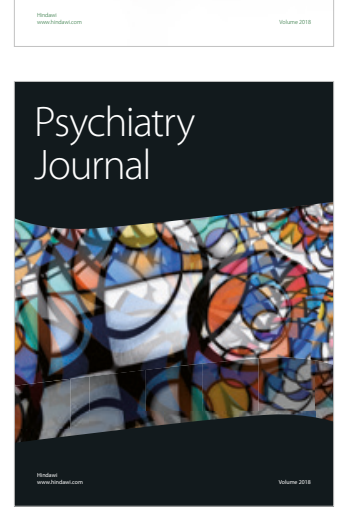
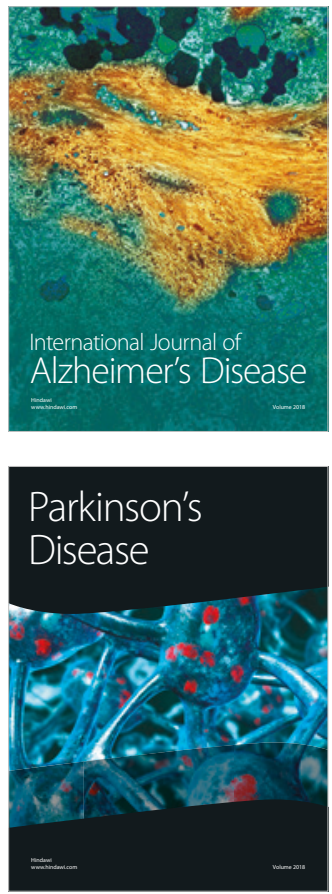
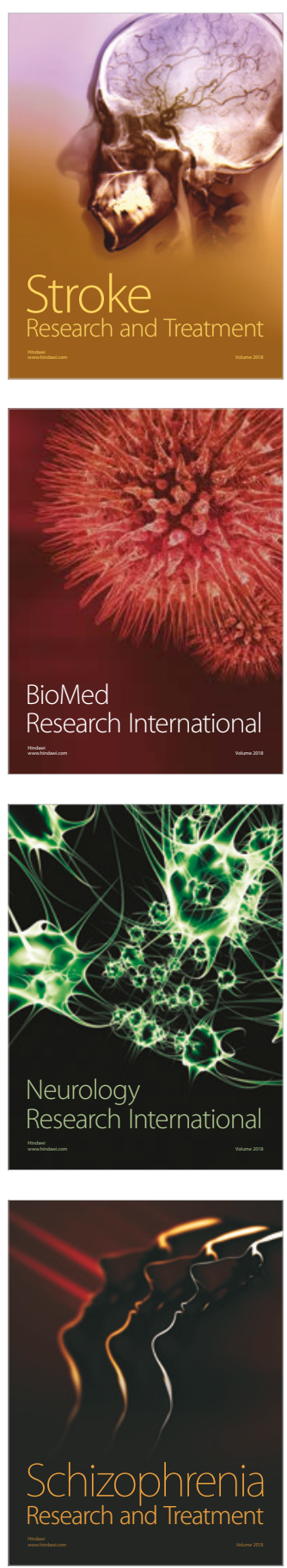